\title{
EXPLORING THE BARRIERS TO EFFECTIVE COOPERATIVE LEARNING IMPLEMENTATION IN SCHOOL MATHEMATICS CLASSROOMS
}

\author{
Angel Mukuka, Vedaste Mutarutinya \\ University of Rwanda, Republic of Rwanda \\ E-mail: mukukaangel@yahoo.com, vedastemuve@yahoo.fr
}

Sudi Balimuttajjo

Mbarara University of Science \& Technology, Uganda

E-mail: sudib@must.ac.ug

\begin{abstract}
Literature is replete with research confirming the benefits of cooperative learning on students' academic achievement and attitude towards mathematics. Despite these benefits, cooperative learning implementation in most Zambian secondary school mathematics classrooms has remained a challenge. An explanatory sequential mixed methods research design was employed to determine the causes of teacher-resistance to cooperative learning implementation in selected schools. A cluster random sampling method was used to select 62 teachers $(43$ male and 19 female) of mathematics from six public secondary schools in Ndola district of Zambia. A questionnaire was administered to all the 62 teachers followed by lesson observations in six randomly selected grade 11 mathematics classrooms, whose teachers later attended a focus group discussion. Research findings revealed that the majority of participants prefer expository teaching to cooperative learning. More than $64 \%$ of the participants indicated that they resisted implementing cooperative learning in their classrooms due to shortcomings in; assessing learners, ensuring a disciplined class environment, completing the already bulky syllabus, handling large classes, students'low reasoning abilities and preparation time versus high teaching loads. These results provide evidence on the need for more attention to how the identified challenges could be addressed not only in Zambian mathematics classrooms but in other educational settings elsewhere.
\end{abstract}

Keywords: cooperative learning, expository teaching, mathematics classrooms, mixed methods research.

\section{Introduction}

The ability to cooperate with others has been one of the most desired attributes for individual citizens to cope with the demands of the $21^{\text {st }}$ century workplaces and educational environments. It is a well-known fact that teamwork maximizes the strengths of team members while minimizing their weaknesses. Cooperation also brings about work and educational environments that are dynamic, productive and efficient.

\section{Theoretical Perspectives}

In classroom setting, the need for students to work cooperatively stems from the theory of constructivism, which requires students to interact and get engaged with knowledge construction, and teachers to work as facilitators or guides (Davidson \& Major, 2014). Other 
Angel MUKUKA, Vedaste MUTARUTINYA, Sudi BALIMUTTAJJO. Exploring the barriers to effective cooperative learning implementation in school mathematics classrooms

PROBLEMS

OF EDUCATION IN THE $21^{\text {st }}$ CENTURY Vol. 77, No. 6, 2019

leading proponents of cooperative learning (e.g. Butera \& Buchs, 2019; Johnson \& Johnson, 2015; Slavin, 2015) have identified more psycho-social theoretical perspectives that support cooperative environments more than the individual and competitive ones. These include the motivational, social cohesion, cognitive development/elaboration, behavioral and the social interdependence theories of learning. Although some disagreements on why and how cooperative learning affects academic achievement might have arisen among different groups of scholars and researchers, Slavin (2015) has guided that scholars or researchers who subscribe to different theoretical perspectives of cooperative learning need to start viewing other perspectives as complementary rather than contradictory. Viewing all cooperative learning theoretical perspectives as being complementary to one another would enable teachers to improve students' interactions with one another, and eventually lead to enhanced academic achievement.

Similarly, the formulation of a new curriculum for Zambian secondary schools (Curriculum Development Centre, 2013) was greatly influenced by a constructivist conception. Like many other mathematics curricula elsewhere (see Baloche \& Brody, 2017; Sharan, 2010), the Zambian curriculum for secondary school mathematics recommends an education environment where students can interact with peers as they create meaning and construct new knowledge. Therefore, enabling students to learn mathematics in a cooperative group setup may offer support to such an environment. Cooperative learning enables learners to interact in small groups to gain an understanding of the subject matter, complete a given task or meet a set target. Brodie (2010) has argued that "learners' inability to see mathematics as a worthwhile human activity is in part due to low levels of collaboration in their classrooms" (p.59). This provides evidence on the need for teachers of mathematics to employ approaches such as cooperative learning, where students can develop and investigate mathematical conjectures, draw conclusions, and share or debate mathematical ideas through peer interactions.

Through extensive research that has been conducted at different grade levels and settings, various practical approaches to cooperative learning have been generated and evaluated (see Slavin, 2015). Two major categories of cooperative learning have emerged. That is, Structured Team Learning (STL) and Informal Group Learning (IGL) methods. Each of these two categories consist of different types/models. Ghaith (2018) has provided a table describing each of those cooperative learning models, their respective proponents and the conditions under which each model could be implemented effectively (p.387). STL methods involve group rewards on the basis of students' learning progress and individual accountability. This implies that the success of the team is more dependent on individual contributions than group products. On the other hand, IGL methods are concerned with the social dynamics and not masterly of the specified content.

\section{Research Problem and Focus}

Educational literature is abundantly supplied with research (e.g., Borůvková \& Emanovský, 2016; Entonado \& García, 2003; Kramarski \& Mevarech, 2003; Navarro \& Gallardo, 2015; Slavin, 1995; Yaduvanshi, S., \& Singh, 2019) that have found cooperative settings more beneficial than individual and competitive ones. It has been revealed that cooperative learning environments lead to improved academic performance, higher order thinking and reasoning, self-confidence, and more social interactions. Despite all these and other benefits, cooperative learning implementation has been challenging for teachers not only in Zambian secondary schools but in other settings elsewhere (see Baloche \& Brody, 2017; Buchs, Filippou, Pulfrey, \& Volpé, 2017; Ghaith, 2018; Le, Janssen, \& Wubbels, 2018). Worse still, none of the research conducted in Zambia, and possibly many other Sub-Saharan African countries has attempted to understand why most teachers in secondary school mathematics 
Angel MUKUKA, Vedaste MUTARUTINYA, Sudi BALIMUTTAJJO. Exploring the barriers to effective cooperative learning implementation in school mathematics classrooms

PROBLEMS

OF EDUCATION

IN THE $21^{\text {st }}$ CENTURY

Vol. 77, No. 6, 2019

classrooms have continued their hold to expository teaching as opposed to the recommended learner-centered approaches such as cooperative learning. The main aim of this research was to understand why most teachers from the selected schools had been resisting to utilize cooperative learning in their mathematics classrooms amidst all its perceived benefits.

Based on the research problem highlighted above, answers to the following research questions were sought:

(i) Which is the most dominant teaching method in selected school mathematics classrooms?

(ii) What are the most significant causes of teacher-resistance to cooperative learning implementation in their mathematics classrooms?

(iii) How could the identified challenges be addressed to ensure that cooperative learning is implemented effectively in those classrooms?

It was anticipated that answers to the above research questions could provide future researchers and practitioners with deeper insights into the most appropriate cooperative learning models for Zambian school mathematics classrooms and other similar contexts worldwide.

\section{Research Methodology}

\section{Research Design}

An explanatory sequential mixed methods research design was employed in this research. In line with the pragmatic world view (Creswell, 2014), this research combined both quantitative and qualitative approaches to get more complete data to answer the stated research questions. A mixed-methods research approach was considered appropriate for this phase of data collection to gain deeper insights into the prevailing situation before implementation of the intervention that was done about one month later.

\section{Research Participants}

Research participants were drawn from 6 public secondary schools within Ndola district of Zambia. Sixty-two (43 male and 19 female) teachers of mathematics turned up for this research, six of which participated in a focus group discussion two weeks after completing the questionnaire. Respondents' mathematics teaching experience at secondary school level ranged from 1 to 27 years $(M=11.37, S D=7.03)$. Cluster random sampling method was used to select the participants. Public secondary schools within Ndola District were categorized into three clusters according to their academic average performance in national examinations (i.e. high performing, moderate and low performing). Two schools were randomly selected from each cluster and then all mathematics teachers at each of the selected schools were requested to complete the questionnaire. Thereafter, one teacher of a grade 11 class was randomly selected from each participating school. Each of the six teachers were then observed in their grade 11 mathematics classes, and later attended a focus group discussion.

\section{Research Instruments and Validation Procedures}

The questionnaire comprised four sections namely; demographic information, development of students' mathematical reasoning, mathematics teaching methods and the perceived barriers to effective cooperative learning implementation. However, only the last two sections of the questionnaire have been reported because they are deemed appropriate for 
Angel MUKUKA, Vedaste MUTARUTINYA, Sudi BALIMUTTAJJO. Exploring the barriers to effective cooperative learning implementation in school mathematics classrooms

PROBLEMS

OF EDUCATION IN THE $21^{\text {st }}$ CENTURY Vol. 77, No. 6, 2019

748

addressing the stated research questions. Each of those questionnaire items was formulated in line with previous research on how teaching methods influence students' achievement in mathematics (Haas, 2002) and the perceived barriers to effective cooperative learning implementation (Aksit, Niemi, \& Nevgi, 2016; Buchs et al., 2017). This was done to ensure that only items similar to the ones that have been previously validated and checked for reliability were included in the questionnaire. Nevertheless, reliability analysis and validation were carried out before administering the questionnaire since the context and purpose of the present research were different from the previous ones.

An exploratory factor analysis was carried out using the principal component extraction method in SPSS version 20. Following recommendations by Guadagnoli and Velicer (1988), 22 out of the initial 28 items on 3 teaching methods met the criteria (i.e. factor loadings of .4 or more) and were all retained. The retained items were then analyzed for internal consistency and gave a Cronbach alpha of .911. This value was considered acceptable since it was greater than the recommended threshold of .7 (Taber, 2018). Additionally, none of the pairs had inter-item correlations of more than .8. This gave an assurance of the absence of multicollinearity among the items and so all the retained items were independent (Field, 2013). A similar procedure was followed on the barriers to effective implementation of cooperative learning. Only 1 item did not meet the criteria and the other 13 items were retained with Cronbach alpha of .882 . Similarly, none of the pairs of items had correlations of more than .80 .

As pointed out earlier, mathematics lesson observations were also carried out in each of the six schools to confirm the authenticity of teachers' self-reported questionnaire responses and to understand the prevailing mathematics teaching practices in those schools. On the other hand, the purpose of conducting a focus group interview was to gain deeper insights into the motivations behind participants' questionnaire responses and to make a follow-up on what was noticed during lesson observations. Teachers explained why they had been resisting to employ cooperative learning in their classrooms and made suggestions on how those challenges could be addressed.

\section{Data Analysis}

Data from all the three research instruments were analyzed into categories of meaning apropos of participants' responses and the findings from previous studies. Three categories or themes emerged: the prevailing mathematics teaching practices in the selected schools, challenges associated with cooperative learning implementation, and the potentially optimum ways through which the use of cooperative learning could be enhanced in school mathematics classrooms. Descriptive statistics such as percentages, mean, standard deviations and standard errors were used to summarize data from questionnaires.

A paired samples t-test was also performed to determine the most dominant teaching method between expository teaching and cooperative learning. Since statistical significance alone does not communicate the magnitude of the treatment or experimental effect, a Cohen's d was calculated using the formula:

$$
d_{s}=\frac{M_{\text {dif }}}{S_{\text {dif }}}
$$

Where symbolizes the sample effect size, the numerator representing the mean difference while the denominator stands for the standard deviation of the difference scores of the paired observations. Lakens (2013) has recommended this formula for calculating effect sizes of paired or correlated observations (p.4).

In line with the recommended procedure for running a paired samples t-test (see Field, 2013; Gaur \& Gaur, 2009), assumptions were checked and it was found that only the 
Angel MUKUKA, Vedaste MUTARUTINYA, Sudi BALIMUTTAJJO. Exploring the barriers to effective cooperative learning implementation in school mathematics classrooms

PROBLEMS

OF EDUCATION

IN THE $21^{\text {st }}$ CENTURY

Vol. 77, No. 6, 2019

normality assumption was violated. Further analysis revealed that the normality assumption could have been violated due to the presence of three extreme outliers in the data. Following the recommended procedure, three cases that produced those outliers were excluded from the analysis and normality test was performed on the remaining sample of 59 respondents. A Shapiro - Wilk $(\mathrm{S}-\mathrm{W})$ normality test was performed on score differences of the paired values (Expository teaching and Cooperative learning) giving $D(59)=.97, p=.204$. Since the $\mathrm{S}-\mathrm{W}$ normality test showed insignificant results $(p>.05)$, it was concluded that the distribution of data was not significantly different from normal. This gave an assurance that a paired samples $t$-test could maintain acceptable levels of type I error thereby producing objective and worthwhile results.

On the other hand, a focus group interview/discussion was audio-recorded, transcribed manually and analyzed qualitatively according to the themes that emerged from data. In line with qualitative data analysis procedures, respondents who provided quotes were identified by pseudonyms. As indicated earlier, lesson observations were carried out to confirm whether what teachers reported in the questionnaires was a true reflection of reality. To achieve that, lesson observations primarily focused on lesson preparation, lesson delivery (introduction, flow or methods used in the lesson activities and conclusion), and overall lesson evaluation.

\section{Ethical Considerations}

Ethical issues were upheld at all stages of data collection and analysis. Before commencement of this research, ethical approval was sought and granted by the Research and Innovations Directorate of the University of Rwanda, College of Education. All participants signed consent forms. Permission to collect data from the selected schools was granted by the Permanent Secretary (Ministry of General Education), Copperbelt Provincial Education Officer and Ndola District Education Board Secretary.

\section{Research Results}

\section{Mathematics Teaching Practices in the Selected Schools}

Teacher ratings for all the items under each teaching method were aggregated, and the overall mean, standard deviation and standard error were generated. To establish the difference between the two teaching methods, a paired samples $t$-test was performed. Table 1 and Table 2 display results for descriptive statistics and paired samples $t$-test respectively.

Table 1. Descriptive statistics on teaching methods.

\begin{tabular}{lllll}
\hline Teaching method & $M$ & $n$ & $S D$ & $S E$ \\
Expository Teaching & 4.16 & 59 & .53 & .07 \\
Cooperative Learning & 3.23 & 59 & .53 & .07 \\
\hline
\end{tabular}


Angel MUKUKA, Vedaste MUTARUTINYA, Sudi BALIMUTTAJJO. Exploring the barriers to effective cooperative learning implementation in school mathematics classrooms

PROBLEMS

OF EDUCATION

IN THE $21^{\text {st }}$ CENTURY

Vol. 77, No. 6, 2019

Table 2. Paired samples t-test for expository teaching (ET) and cooperative learning (CL).

\begin{tabular}{|c|c|c|c|c|c|c|c|c|}
\hline & \multicolumn{5}{|c|}{ Paired Differences } & \multirow[b]{3}{*}{$t$} & \multirow[b]{3}{*}{$d f$} & \multirow[b]{3}{*}{$p$} \\
\hline & \multirow[b]{2}{*}{$M$} & \multirow[b]{2}{*}{$S D$} & \multirow[b]{2}{*}{ SE } & \multicolumn{2}{|c|}{$95 \%$ C.I of the Difference } & & & \\
\hline & & & & Lower & Upper & & & \\
\hline ET-CL & .93 & .51 & .07 & .80 & 1.07 & 14.16 & 58 & .001 \\
\hline
\end{tabular}

Results displayed in Table 1 and Table 2 indicate that, on average, expository teaching was more prevalent $(M=4.16, S D=.53)$ than cooperative learning $(M=3.23, S D=.53)$. This difference of .93, $(95 \%$ CI [.80,1.07]) was significant, $t(58)=14.16, p<.05$, with an effect size, $d=1.82$. According to the benchmarks for the effect size, this value $(d=1.82)$ represents an adequate and large effect (especially that it is greater than the threshold of .8 for a larger effect). Based on these results, it was inferred that besides being statistically significant, this effect is large enough to indicate that expository teaching was significantly more prevalent than cooperative learning in those classrooms. Despite those classrooms having been dominated by expository teaching methods (i.e. at an average of 4 in every 5 consecutive class periods), questionnaire responses indicated that cooperative learning had also been implemented substantially (i.e. at an average of 3 out of 5 consecutive class periods).

Although questionnaire responses revealed that teachers had been using cooperative learning in their classrooms, it was noticed through lesson observations that none of those lessons implemented or utilized cooperative learning accordingly. Lesson observations also revealed that the majority of teachers did not understand what constitutes effective cooperative learning implementation in their classrooms. For instance, there were some instances where the teacher could ask students to work in groups but without clear guidelines given to them. That resulted in groups having one or two students dominating the discussions while the rest remained passive.

Besides that, there were cases where group work was included in the lesson plan but was never used until the end of the lesson. This was because the majority of teachers spent so much time explaining concepts to the learners thereby leaving little time for them to work collaboratively on the given problem-solving tasks.

Another practice that was common during lesson observations was a situation where a teacher could invite one student to present the solution on the chalkboard while other students were requested to listen attentively and to clap for their classmates after the presentation. Although this might be a good practice, most of those presenters did not explain the procedures to their classmates but only ended up writing down the solutions while the rest of the students were busy copying those solutions without proper understanding. Students' conceptual understanding was assessed through class exercises that were done individually in most cases or pairs in a few cases. In all, lesson observations confirmed that expository teaching methods dominated most of the classrooms and none of the observed lessons implemented cooperative learning accordingly.

\section{Teachers' Perceptions regarding Barriers to Effective Cooperative Learning Implementation}

Table 3 illustrates the frequency of the extent to which the respondents (teachers) agreed or disagreed with each of the barriers to cooperative learning implementation. The following criteria were used:

$1=$ strongly disagree, $2=$ disagree, $3=$ not sure, $4=$ agree, $5=$ strongly agree. 
Angel MUKUKA, Vedaste MUTARUTINYA, Sudi BALIMUTTAJJO. Exploring the barriers to effective cooperative learning implementation in school mathematics classrooms

Results displayed in Table 3 indicate that a substantial number (more than 50\%) of respondents tended to agree or strongly agree that the following perceived barriers had a negative impact on cooperative learning implementation in their mathematics classrooms: large class size (93.6\%), alignment with the examination system $(87.1 \%)$, inadequate or lack of resources $(85.5 \%)$, preparation time versus high teaching loads $(85.4 \%)$, students' poor communication skills $(79 \%)$, difficulties in preparing and organizing learners to cooperate $(71 \%)$, difficulties in assessing and monitoring students' progress (67.8\%), students' low reasoning abilities (64.5\%), and lack of orientation or continuing professional development (CPD) workshops (51.6\%).

Table 3 further reflects that only four potential barriers, received a combined agree and strongly agree responses of less than 50\% from the participants. These barriers include inadequate initial teacher training $(20.9 \%)$, learner-centered approaches being viewed as boring by students $(27.5 \%)$, teacher's difficulties in coping with new role as a facilitator $(38.7 \%)$ and students' negative perceptions about cooperative learning (40.6\%).

Table 3. Perceived barriers to effective implementation of cooperative learning.

\begin{tabular}{llllll}
\hline & \multicolumn{5}{c}{ Frequency (\%) } \\
\cline { 2 - 6 } Perceived barrier & 1 & 2 & 3 & 4 & 5 \\
\hline Overcrowded classrooms or large class size & 0 & 6.4 & 0 & 32.3 & 61.3 \\
\hline Alignment with the examination system & 0 & 12.9 & 0 & 45.2 & 41.9 \\
\hline Inadequate or lack of resources & 0 & 8.1 & 6.5 & 46.8 & 38.7 \\
\hline Lack of orientation workshops (CPDs on CL) & 3.2 & 32.3 & 12.9 & 35.5 & 16.1 \\
\hline Inadequate initial teacher training on CL implementation & 22.6 & 35.5 & 21 & 16.1 & 4.8 \\
\hline Teacher's difficulties to cope with new role as a facilitator & 14.5 & 21 & 25.8 & 30.6 & 8.1 \\
\hline Preparation time versus high teaching loads & 0 & 12.9 & 1.6 & 54.8 & 30.6 \\
\hline Learner centered orientation viewed as boring by students & 21 & 22.6 & 29 & 19.4 & 8.1 \\
\hline Difficulties in assessing and monitoring learners' progress & 0 & 32.3 & 0 & 58.1 & 9.7 \\
\hline Difficulties in organizing and preparing learners to cooperate & 0 & 29 & 0 & 48.4 & 22.6 \\
\hline Students' low reasoning abilities may not support CL setups & 0 & 35.5 & 0 & 43.5 & 21 \\
\hline Students' negative perceptions about CL approaches & 12.6 & 24.2 & 22.6 & 25.8 & 14.8 \\
\hline Students' poor communication skills & 0 & 21 & 0 & 51.6 & 27.4 \\
\hline
\end{tabular}

Similar challenges to those reported in Table 3 were also reported during a focus group discussion. Below are some of the notable submissions from the participants on how large class size, lack of preparation time and alignment with the examination system impede the effectiveness of cooperative learning implementation:

MB: Actually, that method (referring to cooperative learning) is more applicable when you are teaching a small class. In large classes, you may spend the whole week on one question.

ML: It is difficult to use group work in those big schools and classes. You may find that students' will pretend to be working or participating only when they see you coming to their group.

MK: The idea of groups does not help at our school because we waste a lot of time. So, if am handling a large class, I usually put them in pairs.

KP: The examination system is too predictable. You can even tell $90 \%$ of the type of questions included in the final examination paper. This promotes rote learning and discourages the use of techniques like cooperative learning by teachers.

PROBLEMS

OF EDUCATION

IN THE $21^{\text {st }}$ CENTURY

Vol. 77, No. 6, 2019 
Angel MUKUKA, Vedaste MUTARUTINYA, Sudi BALIMUTTAJJO. Exploring the barriers to effective cooperative learning implementation in school mathematics classrooms

PROBLEMS

OF EDUCATION

IN THE $21^{\text {st }}$ CENTURY

Vol. 77, No. 6, 2019

752

Inadequate or lack of teaching and learning materials, difficulties in assessing and monitoring students' progress and students' low reasoning abilities were also cited during a focus group discussion as potential barriers to effective cooperative learning implementation. The following submissions from participants suffice:

KP: It is difficult to assess and control students especially when the groups are too big......For instance, a group of 10 students would be difficult to control because you can't even know whether the noise from students is a productive one or not.

MB: Some students fear to be laughed at because of failure to express themselves even when they have a very good answer. So, students' poor communication is also one of the challenges when implementing cooperative learning.

ML: Yes....those whose reasoning ability is low do not participate fully in group work. So, to some extent it is a hindrance and as a teacher, you may not be helping them by giving them group work.

During a focus group discussion, teachers also reported that when learners are put in groups to discuss, most of them just pretend to be participating when they see a teacher coming to their group. Such talk from participants prompted the moderator (researcher) to inquire more from teachers on how they encouraged their students to participate in group work discussions. One of the participants gave the following response:

KP: I usually encourage everyone to participate because presenters are appointed at random. They must be told at the beginning that the person to present from each group will be chosen at random. That way, everyone will make an effort to understand the material during group discussions.

In as much as that idea was lauded by almost all the participants, one of them saw it as a hindrance to those weak students. The participant indicated that weak students would be afraid to be pointed at and as such, it may result in someone dodging classes. On the other hand, the moderator wanted to find out whether teachers needed a lot of resources for them to implement cooperative learning in their classrooms. In reaction, participants indicated that group work is costly not only in terms of time but also the resources and equipment needed. It was further indicated that effective implementation of cooperative learning may demand the availability of things like worksheets, graph papers, flip charts, a projector, drawing equipment for both the teacher and students and most of those things were not always available.

\section{Discussion}

\section{Mathematics Teaching Practices in the Selected Schools}

Based on the findings presented in the previous section, it has been noted that expository teaching methods were still lauded by the majority of teachers of mathematics in those selected schools. Both questionnaire responses and lesson observations revealed that "chalk-and-talk", characterized by a "question and answer" technique dominated those classrooms. Despite being fully aware of the most recommended teaching approaches (see Curriculum Development Centre, 2013), teachers had continued their hold to expository teaching methodologies. Studies conducted in other settings (e.g. Buchs, Filippou, Pulfrey, \& Volpé, 2017; Kartina, Samanhudi, Aisyah, Nulhakim, \& Evendi, 2011; Zakaria \& Iksan, 2007) echo similar findings on the persistence of traditional teaching methods in most mathematics classrooms despite the extensive research literature that has revealed the benefits of other teaching and learning approaches such as cooperative learning.

Additionally, the present research revealed that teachers from those selected schools had been using cooperative learning in about 3 of the 5 consecutive class periods. Although that was reported in the questionnaire responses, none of the observed mathematics lessons utilized cooperative learning effectively. One significant inference that has been drawn here is 
Angel MUKUKA, Vedaste MUTARUTINYA, Sudi BALIMUTTAJJO. Exploring the barriers to effective cooperative learning implementation in school mathematics classrooms

\author{
PROBLEMS \\ OF EDUCATION \\ IN THE $21^{\text {st }}$ CENTURY
}

that those teachers had never been exposed to cooperative learning settings during their initial teacher training in colleges and universities. More so, there are no in-service training workshops organized to orient teachers on how they can implement the newly recommended teaching and learning approaches such as cooperative and problem-based learning. Upon noticing that teachers had been resisting to implement learner-centered teaching and learning approaches such as cooperative learning, a focus group discussion was organized to learn more about the factors hindering them from employing such learning techniques. Most of those factors are discussed in the following section.

\title{
Factors Inhibiting Teachers from Implementing Cooperative Learning in their Classrooms
}

Although cooperative learning has been found helpful to learners' academic performance, their social interactions and attitudes towards mathematics (Ding, Li, Piccolo, \& Kulm, 2010; Hossain \& Ahmad, 2013; Kristina, et al., 1997), most teachers from different settings (see, Buchs et al., 2017; Gillies \& Boyle, 2010; Sharan, 2010) have been struggling to implement such techniques in an effective and efficient manner. The present research equally revealed several challenges associated with cooperative learning implementation in selected secondary school mathematics classrooms.

Firstly, class size was cited as one of the hindrances to effective cooperative learning utilization. Most teachers revealed that cooperative learning was time consuming especially for large classes. Although small classes have been found to be more favorable to both teachers and students (Nye, Hedges, \& Konstantopoulos, 2000), other scholars (e.g. Johnson \& Johnson, 1991; Mulryan, 2010) found that teacher expertise in the determination of student learning was more important than class size. Borůvková and Emanovský (2016) also pointed out that teachers ought to focus more on the peer interaction that enables all the group members to justify their understanding and build upon each other's contributions. In fact, there is a need to understand that cooperative learning could be an effective means of handling a large class because the teacher's main role is more of a consultant than an instructor who might be regarded as the main source of knowledge. Through cooperative learning, students can team up with peers in problem-solving activities and not necessarily relying on a teacher as the only authority.

Secondly, teachers revealed that assessing and controlling learners under a cooperative group setup was quite difficult. Researchers from other settings (e.g., Blatchford, Kutnick, Baines, \& Galton, 2003; Topping, Buchs, Duran, \& Keer, 2017) have also cited similar challenges on teacher resistance to cooperative learning implementation in their classrooms. Teachers opt to use expository teaching methods in their classrooms as those methods are considered well suited for ensuring a disciplined class environment and an easier way to assess learners' academic achievement. However, this is at variance with the principles of a modern constructivist approach, which advocates for learning environments where learners are actively and directly involved in creating meaning and constructing knowledge as opposed to passively receiving information. Hadi et al. (2018) are equally of the view that education in the $21^{\text {st }}$ century should not be regarded as a mere transfer of ready-made knowledge from the teacher to the learner.

Thirdly, students' low caliber or low reasoning ability was seen as an impediment to effective implementation of cooperative learning by most of the teachers. Coupled with poor communication skills, students' failure to express themselves was cited as one of the reasons teachers resist implementing cooperative learning in their classrooms. This challenge is not new, neither is it unique to the Zambian context. Webb (1991) and Webb and Farivar (1994) also observed that students who were not able to communicate effectively were less likely to benefit from cooperative learning. Due to shortcomings in language, such students may 
Angel MUKUKA, Vedaste MUTARUTINYA, Sudi BALIMUTTAJJO. Exploring the barriers to effective cooperative learning implementation in school mathematics classrooms

PROBLEMS

OF EDUCATION IN THE $21^{\text {st }}$ CENTURY Vol. 77, No. 6, 2019

754

find it difficult to explain their reasoning to others, neither could they ask questions nor offer constructive criticism. To effectively overcome such challenges, Gillies \& Boyle (2010) guided that teachers should be oriented on how they can embed cooperative learning methodologies in their classrooms to foster open communication and create an environment where every student feels emotionally secure and supported.

Fourth, teachers reported that the examination system was still based on memorization of facts, which might not require collaboration among students. Besides the examination system being too predictable, it was also revealed that the syllabus was too bulk thereby forcing teachers to teach students to memorize those concepts that are likely to feature in their final examination papers. Like in other previous research (e.g. Aksit, Niemi \& Nevgi, 2016; Buchs et al., 2017; Gillies \& Boyle, 2010; Sharan, 2010) most of the participants indicated that cooperative learning techniques are too demanding in terms of preparation and implementation and so teachers would prefer expository teaching that would enable them to complete the syllabus and make their students pass the exam. However, this is against the guidance provided by the Zambian curriculum for secondary school mathematics (Curriculum Development Centre, 2013), which advocates for teaching the skills that are relevant to addressing societal problems amidst the growing sophistication in science and technology. In view of this, there is a need to orient teachers on how they can effectively implement cooperative learning techniques even in the thick of those challenges.

\section{Suggested Ways for Effective Utilization of Cooperative Learning in Mathematics Classrooms}

Apart from reporting the challenges associated with cooperative learning implementation, teachers made suggestions on how some of the identified challenges could be addressed. Some participants pointed out that there is a need to consider mixing learners with varying aptitudes when forming cooperative groups. Ensuring that each group has a gifted student would be helpful and beneficial to weak students. This suggestion is consistent with what has been recommended by previous researchers (Kramarski \& Mevarech, 2003; Slavin, 2015). Having students to learn in small heterogeneous groups is likely to enhance their communication, creativity, problemsolving and critical thinking skills.

On the other hand, the idea of mixing students with varying aptitudes was not seen as a good way to effective implementation of cooperative learning by some participants. They observed that a group might have performed well because one or two members did the work while the rest assumed the role of a spectator. It was also pointed out that the views of the less able students are not always respected by group members. Teachers were then asked to suggest some ways through which such challenges could be addressed. Most of them were of the view that before the commencement of group work discussions, a teacher ought to have indicated to the learners that the presenter from each group will be chosen at random. They indicated that doing so would be an encouragement for the less able students to seek clarification from the more knowledgeable ones.

The above-stated suggestion could be complemented by Slavin's (2015) recommendation on the need for teachers to design tasks that would enable each group member to learn something. All group members should aspire to spend time clarifying their reasoning to group mates as well as asking for more explanations from their peers. This also suggests the need for teachers to select problem-solving tasks that would enable learners to attain a deeper understanding of various mathematical concepts.

Awarding hardworking and cooperative groups was also viewed as a way of encouraging learners to participate in group work discussions. Teachers indicated that awards should not be restricted to material items only but that students belonging to the same group could be given 
Angel MUKUKA, Vedaste MUTARUTINYA, Sudi BALIMUTTAJJO. Exploring the barriers to effective cooperative learning implementation in school mathematics classrooms

the same mark. Sticking of results for each group on the class notice board could also be an encouragement for learners to cooperate whenever a group task is given.

Lastly, it was also noted that most teachers likened cooperative learning to a mere group work. It was noted that some teachers who attempted to give group work did not explain clearly on how important it was for each group member to participate fully in cooperative group discussions. In view of this, teachers should always try to make it clear to their students that cooperative learning goes beyond a mere group work as it encompasses issues of individual responsibility, accountability and partnership (Le et al., 2018; Navarro \& Gallardo, 2015). In other words, teachers should always make students aware of their individual responsibilities for each group to attain the set targets.

\section{Conclusions and Implications}

Findings of this research show that expository teaching methods have continued to dominate mathematics classrooms in selected public secondary schools of Ndola district in Zambia. Teachers also reported several challenges associated with cooperative learning implementation in their mathematics classrooms. Although some of the findings of this research do not differ significantly from what has been reported previously, this is one of the few studies conducted in Zambia and possibly in other Sub-Saharan African countries where the practitioners (teachers) have made suggestions on what needs to be done to improve cooperative learning implementation in school mathematics classrooms. This appears to be an appropriate way of informing policymakers and other stakeholders about homegrown solutions rather than merely depending on what has been done elsewhere.

It has also been noted that teachers from those selected schools might have not been exposed to effective use of cooperative learning approaches during their initial teacher training as well as in-service professional orientation workshops. Another unique finding was that some teachers believed that the reasoning ability levels of their students were quite low (on average) and so employing cooperative learning in their classrooms could be risky. It has also been noted that the major emphasis by the Zambian education system is on making students pass the national examinations and progress to higher levels of education. This tends to leave teachers with no option but to make use of expository teaching methodologies that seem to be well-suited for them to complete the bulky syllabus and try to make students pass their final examinations.

One notable inference that could be of value at international level is that the number of learners will increase as the population rises, so education systems will have to deal with large classes against inadequate or reducing numbers of teachers. However, a deliberate action of orienting mathematics teachers (in-service and pre-service) in cooperative as well as other learner-centered or active learning methods is required. It is also beneficial to steer away from examination-oriented teaching and curricula because it is detrimental in the long run as it deprives learners of opportunities of authentic learning. Cooperative learning, if properly implemented can assist in reaching the students and offering them a chance to interact with content. For that reason, further research could investigate other possible challenges and how those challenges could be addressed. Further research could also investigate the effects of different cooperative learning models to identify the most appropriate ones for different educational settings worldwide.

\section{References}

Aksit, F., Niemi, H., \& Nevgi, A. (2016). Why is active learning so difficult to implement: The Turkish case. Australian Journal of Teacher Education, 14(4), 93-109. https://doi.org/10.14221/ ajte.2016v41n4.6. 
Angel MUKUKA, Vedaste MUTARUTINYA, Sudi BALIMUTTAJJO. Exploring the barriers to effective cooperative learning implementation in school mathematics classrooms

PROBLEMS

OF EDUCATION IN THE $21^{\text {st }}$ CENTURY Vol. 77, No. 6, 2019

756

Baloche, L., \& Brody, C. M. (2017). Cooperative learning: exploring challenges, crafting innovations. Journal of Education for Teaching, 43(3), 274-283. https://doi.org/10.1080/02607476.2017.131 9513.

Blatchford, P., Kutnick, P., Baines, E., \& Galton, M. (2003). Toward a social pedagogy of classroom group work. International Journal of Educational Research, 39(1-2), 153-172.

Borůvková, R., \& Emanovský, P. (2016). Small group learning methods and their effect on learners' relationships. Problems of Education in the 21st Century, 70, 45-58.

Brodie, K. (2010). Teaching Mathematical reasoning in secondary school classrooms. New York: Springer Science \& Business Media Dordrencht. https://doi.org/10.1007/978-0-387-09742-8.

Buchs, C., Filippou, D., Pulfrey, C., \& Volpé, Y. (2017). Challenges for cooperative learning implementation: Reports from elementary school teachers. Journal of Education for Teaching, 7476(May), 1-11. https://doi.org/10.1080/02607476.2017.1321673.

Butera, F., \& Buchs, C. (2019). Social Interdependence and the promotion of cooperative learning. In K. Sassenberg \& M. Vliek (Eds.), Social psychology in action (pp. 111-127). Cham: Springer. https://doi.org/10.1007/978-3-030-13788-5_8.

Creswell, J. (2014). Research design: Quantitative, qualitative and mixed methods approaches (4 ${ }^{\text {th }}$ ed.). Los Angeles, London, New Delhi: SAGE Publications.

Curriculum Development Centre. (2013). O level secondary school mathematics syllabus Grade 10-12. Lusaka, Zambia: Ministry of General Education.

Davidson, N., \& Major, C. H. (2014). Boundary crossings: Cooperative learning, collaborative learning, and problem-based learning. Journal on Excellence in College Teaching, 25(3 \& 4), 7-55.

Ding, M., Li, X., Piccolo, D., \& Kulm, G. (2010). Teacher interventions in cooperative-learning mathematics classes. The Journal of Educational Research, 100(3), 37-41. https://doi.org/10.3200/ JOER.100.3.162-175.

Entonado, F. B., \& García, S. M. (2003). Co-operative learning in the teaching of mathematics in secondary education. Educational Action Research, 11(1), 93-120. https://doi. org/10.1080/09650790300200202.

Field, A. (2013). Discovering statistics using SPSS (4 ${ }^{\text {th }}$ ed.). London: SAGE.

Gaur, A. S., \& Gaur, S. . (2009). Statistical methods for practice: A guide to data analysis using SPSS (Second ed.). Washington DC: SAGE Publications. Retrieved from www.sagepublications.com.

Ghaith, G. M. (2018). Teacher perceptions of the challenges of implementing concrete and conceptual cooperative learning. Issues in Educational Research, 28(2), 385-404.

Gillies, R. M., \& Boyle, M. (2010). Teachers' reflections on cooperative learning: Issues of implementation. Teaching and Teacher Education, 26(4), 933-940. https://doi.org/10.1016/j.tate.2009.10.034.

Guadagnoli, E., \& Velicer, W. F. (1988). Relation of sample size to the stability of component patterns. Psychological Bulletin, 103(2), 265-275.

Haas, M. S. (2002). The influence of teaching methods on student achievement on Virginia's end of course standards of learning test for algebra I. Virginia Polytechnic Institute and State University.

Hadi, S., Retnawati, H., Munadi, S., Apino, E., \& Wulandari, N. F. (2018). The difficulties of high school students in solving higher-order thinking skills problems. Problems of Education in the 21st Century, 76(4), 520-532.

Hossain, A., \& Ahmad, R. (2013). Effects of cooperative learning on students ' achievement and attitudes in secondary mathematics. In F. Odabaşı (Ed.), 3rd World conference on learning, teaching and educational leadership (WCLTA-2012) (Vol. 93, pp. 473-477). Elsevier B.V. https://doi. org/10.1016/j.sbspro.2013.09.222.

Johnson, D. W., \& Johnson, R. T. (1991). Learning mathematics and cooperative learning lesson plans for teachers. Edina, MN: Interaction Book.

Johnson, D. W., \& Johnson, R. T. (2015). Theoretical approaches to cooperative learning. In R. Gillies (Ed.), Collaborative learning: Developments in research and practice (pp. 17-46). New York: Nova.

Kartina, I., Samanhudi, U., Aisyah, S., Nulhakim, L., Evendi, S. S., \& Faturohman, M. (2011). Active learning and student engagement in mathematics. Excellence in Higher Education, 2(2), 109-113. https://doi.org/doi: 10.5195/ehe.2011.60 | http://ehe.pitt.edu.

Kramarski, B., \& Mevarech, Z. R. (2003). Enhancing mathematical reasoning in the classroom: The effects of cooperative learning and metacognitive training. American Educational Research Journal, 40(1), 281-310. https://doi.org/10.3102/00028312040001281. 
Angel MUKUKA, Vedaste MUTARUTINYA, Sudi BALIMUTTAJJO. Exploring the barriers to effective cooperative learning implementation in school mathematics classrooms

PROBLEMS

OF EDUCATION

IN THE $21^{\text {st }}$ CENTURY

Vol. 77, No. 6, 2019

Kristina, M, W., Linda, B., \& John, A. N. (1997). Cooperative learning in the secondary mathematics classroom. The Journal of Educational Research, 91(1), 37-41. https://doi. org/10.1080/00220679709597519.

Lakens, D. (2013). Calculating and reporting effect sizes to facilitate cumulative science: A practical primer for t-tests and ANOVAs. Frontiers in Psychology, 4, 1-12. https://doi.org/10.3389/ fpsyg.2013.00863.

Le, H., Janssen, J., \& Wubbels, T. (2018). Collaborative learning practices: Teacher and student perceived obstacles to effective student collaboration. Cambridge Journal of Education, 48(1), 103-122. https://doi.org/10.1080/0305764X.2016.1259389.

Mulryan-kyne,C.(2010). Teaching largeclasses atcollegeanduniversitylevel: Challenges and opportunities. Teaching in Higher Education, 15(2), 175-186. https://doi.org/10.1080/13562511003620001.

Navarro, M., \& Gallardo, E. J. (2015). Teaching to training teachers through cooperative learning. Procedia - Social and Behavioral Sciences, 180, 401-406. https://doi.org/10.1016/j.sbspro.2015.02.136.

Nye, B., Hedges, L., \& Konstantopoulos, S. (2000). The effect of small classes on academic achievement: The results of the Tennessee class size experiment. American Educational Research Journal, 37(1), 123-151. https://doi.org/10.3102/00028312037001123.

Sharan, Y. (2010). Cooperative learning for academic and social gains: Valued pedagogy, problematic practice. European Journal of Education, 45(2), 300-313.

Slavin, R. E. (2015). Cooperative learning in schools. In International Encyclopedia of Social \& Behavioral Sciences (2 ${ }^{\text {nd }}$ ed., Vol. 4, pp. 881-886). York: Elsevier Ltd. https://doi.org/10.1016/ B978-0-08-097086-8.92028-2.

Taber, K. S. (2018). The use of Cronbach's alpha when developing and reporting research instruments in science education. Research in Science Education, 48(6), 1273-1296. https://doi.org/10.1007/ s11165-016-9602-2.

Topping, K. J., Buchs, C., Duran, D., \& Keer, H. Van. (2017). Effective peer learning: From principles to practical implementation. London and New York: Routledge.

Webb, N. M. (1991). Task-Related verbal interaction and mathematics learning in small groups. Journal for Research in Mathematics Education, 22(5), 366-389. https://doi.org/10.2307/749186.

Webb, Noreen M., \& Farivar, S. (1994). Promoting helping behavior in cooperative small groups in middle school mathematics. American Educational Research Journal, 31(2), 369-395.

Yaduvanshi, S., \& Singh, S. (2019). Fostering achievement of low-, average-, and high-achievers students in biology through structured cooperative learning (STAD method). Education Research International, Article ID 1462179, 1-10. https://doi.org/10.1155/2019/1462179.

Zakaria, E., \& Iksan, Z. (2007). Promoting Cooperative Learning in Science and Mathematics Education: A Malaysian Perspective. Eurasia Journal of Mathematics, Science \& Technology Education, 3(1), 35-39.

Received: August 29, 2019

Accepted: November 20, 2019

\begin{tabular}{|ll}
$\begin{array}{l}\text { Angel Mukuka } \\
\text { (Corresponding author) }\end{array}$ & $\begin{array}{l}\text { MSc, Ph.D. Scholar, African Centre of Excellence for Innovative Teaching and Learning } \\
\text { Mathematics \& Science, University of Rwanda, College of Education, Republic of Rwanda. } \\
\text { E-mail: mukukaangel@yahoo.com } \\
\text { ORCID iD: https://orcid.org/0000-0003-0292-1324 }\end{array}$ \\
\hline Vedaste Mutarutinya & $\begin{array}{l}\text { Ph.D., Senior Lecturer of Mathematics, University of Rwanda, College of Education (UR- } \\
\text { CE), School of Education, Department of Mathematics, Science and Physical Education, } \\
\text { Republic of Rwanda. } \\
\text { E-mail: vedastemuve@yahoo.fr }\end{array}$ \\
& $\begin{array}{l}\text { Ph.D., Senior Lecturer of Mathematics Education, Department of Educational Foundations } \\
\text { Sudi Balimuttajjo }\end{array}$ \\
& E-mail: sudib@must.ac.ug
\end{tabular}

